\title{
FIZYCZNA PRZESTRZEŃ SZKOŁY - WSPÓŁCZESNE KIERUNKI PROJEKTOWE
}

\author{
Wojciech Kocki ${ }^{2}$ Jacek Bogucki ${ }^{1}$, Bartłomiej Kwiatkowski \\ ${ }^{1}$ Warszawska Wyższa Szkoła Humanistyczna im. Bolesława Prusa \\ ${ }^{2}$ Politechnika Lubelska, Wydział Budownictwa i Architektury, Katedra Architektury, \\ Urbanistyki i Planowania Przestrzennego Politechniki Lubelskiej.
}

\begin{abstract}
Streszczenie. Współczesne kierunki projektowe obiektów szkolnych znacząco zmieniły się od lat osiemdziesiątych uwzględniając sposób użytkowania oraz poszukiwanie wartości dodanych, niezwiązanych bezpośrednio z nauką ale stwarzających pretekst do przebywania w przestrzeni obiektu i indywidualizowania jej w zależności od potrzeb. Duże znaczenie dla projektantów mają osiągniecia naukowe psychologii środowiskowej badającej kształtowanie przestrzeni i jej interakcje z człowiekiem.
\end{abstract}

Słowa kluczowe: szkoła, psychologia środowiskowa, projektowanie, fizyczna przestrzeń, kierunki projektowe

Postępujące zmiany ekonomiczne, społeczne, kulturowe oraz technologiczne stawiają przed współczesną szkołą coraz ważniejsze zadania. Szkoła powinna stać się miejscem kształtowania osobowości człowieka odpowiednio przygotowanego do funkcjonowania w nowoczesnej i zmieniającej się przyszłości. Znany futurolog amerykański Alvin Toffler wskazywał, iż w nowoczesnym społeczeństwie „Edukacja powinna wynikać z obrazu przeszłości zarazem (...) w oparciu o teraźniejszość kształtować obraz świata jutra” Znany futurolog amerykański Alvin Toffler wskazywał, iż w nowoczesnym społeczeństwie „Edukacja powinna wynikać z obrazu przeszłości zarazem (...) w oparciu o teraźniejszość kształtować obraz świata jutra"1 Myślenie o przyszłości nie powinno wzbudzać u młodych ludzi obaw, pesymistycznych myśli, poczucia zagrożenia - powinna jawić się jako zadanie i wyzwanie, które podejmie w oparciu o posiadaną wiedzę i umiejętności ${ }^{2}$.

Realizacja tak ważnego zadania spoczywa na systemie szkolnym, którego definicje najczęściej akcentują aspekty instytucjonalne. Znany polski pedagog W. Okoń, system oświatowy określa jako „ogół szkół i przedszkoli wraz z nauczycielami, uczniami (studentami), programami, bazą lokalowo - terenową, instytucjami finansującymi szkoły i innymi instytucjami społecznymi i kulturalnymi”3. O ile w literaturze pedagogicznej można znaleźć ogromną ilość prac dotyczących problematyki dydaktyki i wychowania uczniów, kształcenia oraz funkcjonowania zawodowego nauczycieli, analiz programów nauczania, problematyki organizacji systemu wsparcia szkoły przez inne instytucje a nawet finansowania szkół, o tyle bardzo nieliczne są prace poświęcone zagadnieniom związanym z rolą i znaczeniem fizycznej przestrzeni szkoły (w definicji Okonia określanej mianem bazy lokalowo - terenowej) w procesie edukacji, podczas gdy oddziaływanie fizycznej przestrzeni na człowieka staje się w chwili obecnej jednym z najważniejszych czynników, branych pod uwagę w wszelkiego rodzaju pracach projektowych i architektonicznych. Zjawisko to zauważa znany polski pedagog A. Nalaskowski (pionier w dziedzinie badań nad fizyczną przestrzenią polskiej szkoły), pisząc „To zdumiewające, ale poza nielicznymi wyjątkami zawartymi w niewielu pozycjach pedagogicznych problem gmachu szkolnego praktycznie nie istniał. Przy czym muszę dodać, że przez

1 Toffler 2000

2 Borowik 2010

3 Okoń 1984 
problem gmachu szkolnego rozumiem zarówno jego bryłę, jak i zawartą w niej przestrzeń, otaczającą go infrastrukturę i drogi doń wiodące, stanowiące zespół bodźców oddziałujących codziennie na dziecko"4. Problem fizycznej przestrzeni szkoły i jego związku z procesem dydaktyczno-wychowawczym wydawał się być w naszym kraju, niedostrzeganym i trochę „niewartym” głębszej - w tym naukowej- refleksji.

Tymczasem w krajach zachodnich stanowił przedmiot dociekań i badań, szczególnie ze strony psychologów. Poznaniem natury owego oddziaływania zajmuje się między innymi dziedzina psychologii zwana psychologią środowiskową. Główne kierunki rozważań teoretycznych oraz praktycznych w ramach psychologii społecznej dotyczą poznania związku pomiędzy fizycznym środowiskiem człowieka a jego funkcjonowaniem emocjonalnym, społecznym oraz intelektualnym ${ }^{5}$. Istnienie takiego związku dostrzegane jest $\mathrm{w}$ bardzo wielu aspektach funkcjonowania człowieka, w tym również w dziedzinie szeroko pojmowanej edukacji. Jak pisze A. Bańka, twórca pierwszego w naszym kraju opracowania dotyczącego psychologicznych aspektów owego związku, „współczesna psychologia tym się charakteryzuje, że świadomie zmierza do rozwiązywania problemów edukacji, pracy, rehabilitacji, zdrowia, rekreacji i rozwoju człowieka w ścisłym związku z rozwiązywaniem problemów jakości środowiska." ${ }^{\circ}$.

W sposób naturalny więc, problematyka dotycząca znaczenia psychologii środowiskowej w rozwoju i modernizacji oświaty znalazła się w kręgu zainteresowania instytucji zajmujących się edukacją. Zagadnienia istotne dla środowiska uczenia się w XXI wieku zostały zdefiniowane przez OECD, w dokumentach dotyczących planowania i projektowania budynków i infrastruktury dla celów edukacyjnych (OECD/PEB). Czołowi architekci i specjaliści z dziedziny edukacji, zwrócili uwagę na 7 aspektów, wymagających głębokiej refleksji w nowoczesnych społeczeństwach: projektowanie szkoły w zmieniającym się świecie; wpływ nowych technologii na projekt szkoły; zwiększony dostęp do edukacji poprzez odpowiednio zaprojektowaną szkołę; zaprojektowanie przyjaznych przestrzeni uczniom i nauczycielom, komfortowych budynków szkolnych; włączenie w projektowanie szkoły wszystkich zainteresowanych; obiekty oświatowe jako narzędzie edukacyjne; zapewnienie wysokiej jakości projektu szkoły ${ }^{7}$. Nowocześnie zaprojektowane, (w oparciu o wyżej wymienione zagadnienia) szkoły mogą przyczynić się w dużym stopniu do podniesienia jakości edukacji i osiągnięcia stawianych przed nią celów i zadań. Zagadnienia te nie dotyczą tylko i wyłącznie problematyki nauczania i procesu wychowania w czasie zajęć lekcyjnych ale obejmują również działalność pozalekcyjna szkoły, a w szczególności zagadnienia związane z zagospodarowanie w sposób prawidłowy czasu wolnego dzieci i młodzieży. J. Izdebska przedstawia czas wolny dziecka jako „okres, który pozostaje mu po wypełnieniu obowiązków szkolnych, domowych, czynności organizacyjno-porządkowych, związanych z zachowaniem zdrowia i higieny, czas, w którym może ono wykonywać czynności według swego upodobania, związane z wypoczynkiem, rozrywką i zaspokajaniem potrzeb wynikających z własnych zainteresowań. Czas wolny obejmuje także okres, w którym wypełniają one dobrowolnie przyjęte obowiązki społeczne"s. Ogromne znaczenie zagospodarowania czasu wolnego młodych ludzi, można rozpatrywać w 3 aspektach: ,aspekt socjologiczny - dziecko w zasadzie czas wolny powinno spędzać w grupie rówieśników; czas spędzony wyłącznie w samotności uniemożliwiłby mu bardzo ważną rzecz: porównanie własnego postępowania, swoich czynów z innymi; aspekt psychologiczny - intensywnie rozwijająca się psychika dziecka wymaga wciąż nowych bodźców, wrażeń. Rozwijającej się psychice

\footnotetext{
4 Nalaskowski 2013

5 Gilford 2007

6 Bańka 2002

OECD 2006

Izdebska 1978
} 
nie wystarczy nauka szkolna i praca. Dziecko pragnie samodzielnie poszukiwać interesujących je rzeczy, zjawisk. W miarę wzrostu odkrywa i krystalizuje osobiste zamiłowania, próbuje samodzielnie określić swoje zainteresowania i uzdolnienia. W zajęciach czasu wolnego dużą rolę odgrywają potrzeby: rozrywki, przyjemności i zadowolenia po trudach nauki, wysiłku umysłowego. Radość zabawy przynosi dziecku odprężenie fizyczne i psychiczne. Radosna zabawa, umiejętnie i rozumnie kierowana, wnosi do dziecięcej psychiki elementy wychowawcze i kształcące, które przyczyniają się do jej prawidłowego rozwoju; aspekt pedagogiczny - pedagogiczna wartość czasu wolnego polega na tym, że stwarza on sytuacje, w których dzieci i młodzież przejawiają inicjatywę, aktywność, umiejętność organizowania sobie zajęć wykraczających poza program ich codziennych obowiązków, a występujących jako odrębne, wolne momenty dnia, z którymi trzeba i należy coś począć. W wolnym czasie dzieci i młodzież mają szansę na przejawianie własnej inicjatywy i samodzielności. Jednym z dodatnich elementów pedagogicznych aspektów czasu wolnego jest dochodzenie przez samo dziecko do zrozumienia konieczności samowychowania, stałego podnoszenia swoich umiejętności oraz ich doskonalenia"'.

Inwestycja $\mathrm{w}$ dobrze opracowaną przestrzeń fizyczną przynosi więc wiele korzyści dla procesu edukacji. W chwili obecnej, uważa się iż „wystrój i sposób adaptacji miejsca, w jakim się ona odbywa, warunkuje:

- zdrowy rozwój dzieci,

- ich pomyślną adaptację do środowiska szkolnego,

- jakość kontaktów społecznych, budowanie atmosfery życzliwości,

- stworzenie możliwości uczenia się rozumienia otaczającego świata,

- stymulowanie samodzielnych działań dziecka, budujących jego wiedzę i umiejętności." Niestety w naszym kraju brakuje dokumentów określających zasady projektowania przyjaznych (uwzględniających dokonania psychologii środowiskowej szkół), które mogłyby być podstawa oceny szkoły lub wyznaczać kierunki jej modernizacji. Głównymi wymogami branymi pod uwagę $\mathrm{w}$ takich wypadkach są przepisy $\mathrm{BHP}^{11}$ określające (chociaż też często „miękkim” życzeniowym językiem, dla przykładu „Wskazane jest zapewnienie dzieciom sali rekreacyjnej do wypoczynku i zabaw ruchowych."

Niezwykle istotnym elementem, wpływającym na funkcjonowanie szkoły jest jej lokalizacja i interakcja $\mathrm{z}$ otoczeniem. Odpowiednie usytuowanie budynku może znacząco wpłynąć na komfort dojścia oraz dojazdu do głównego wejścia, komunikację z traktami pieszymi oraz najbliższymi przestrzeniami publicznymi w formie placów, parków bądź pasów zieleni. Główne czynniki, które wpływają na komfort psychiczny uczniów (jak dowodzą badania Petera Baretta oraz Yufan Zhanga, Design Implications for Primary Schools) ${ }^{12}$ to jakość nasłonecznienia, akustyka wnętrz, temperatura oraz jakość powietrza. Odpowiednie zorientowanie budynku względem stron świata oraz właściwa proporcja pomiędzy ilością przeszkleń a powierzchnią pomieszczenia wpływa na komfort nauczania - jasne wnętrza z dużą ilością światła słonecznego potrzebnego dla zdrowej pracy oka wpływają korzystnie na prawidłowa ostrość przedmiotów. Drugim z istotnych czynników kształtujących jakość fizycznej przestrzeni jest jej akustyka. Analizy lokalizacji budynku mogą w znacznym stopniu wspomóc proces projektowy między innymi wskazaniem obszarów narażonych na niepożądany stopień hałasu. Jakość akustyczna oraz możliwość kontrolowania poziomu hałasu w pomieszczeniu to główne czynniki wpływające na komfort jego wykorzystywania. Pomieszczenia prawidłowo odizolowane od źródeł nadmiernego hałasu mogą znacznie wpłynąć na jakość komunikacji oraz na

9 Matyjas 2003

10 Skorodzień 2013

11 Cichy, Strumińska-Doktór 2010

12 Barrett, Zhang 2009 
poziom nauki i pracy. Izolacją akustyczną mogą być rozwiązania materiałowe (elewacyjne bądź wewnętrzne tj. materiały pochłaniające w dużym stopniu hałas wykorzystywane jako wykończenie posadzki, ściany lub sufitu, zasłon okiennych, mebli) a także rozwiązania funkcjonalne rzutu obiektu poprzez lokalizację toalet, pomieszczeń pomocniczych, oraz korytarzy po stronie narażonej na nadmierny hałas - mogą spełniać rolę bariery wyciszającej. Kolejnym czynnikiem prowadzącym do podniesienia jakości przestrzeni jest temperatura. Właściwa orientacja względem kierunków świata jest ściśle związana z położeniem geograficznym danego obiektu. Decydującym czynnikiem jest słońce oraz zysk energetyczny promieniowania słonecznego jak i właściwe rozwiązania materiałowe, rodzaj szklenia, jego właściwości, ilości tafli szklanych oraz zastosowania dodatkowych powłok zewnętrznych absorbujących promienie słoneczne. Ostatnim z głównych czynników wpływających na fizyczną przestrzeń szkoły jest jakość powietrza. Odpowiednie analizy lokalizacyjne ukazujące arterie komunikacyjne oraz stopień natężenia ruchu samochodowego i kierunki przewietrzania danego regionu mogą wspomóc proces projektowy poprzez możliwie jak największe wyeliminowanie kontaktu stref pomieszczeń nauki ze źródłami zanieczyszczeń.

Istotnymi elementami w kształtowaniu zagospodarowania terenu oraz decyzji lokalizacyjnych odnośnie obiektu szkoły jest jego odległość od otaczających go innych obiektów tj. budynków zamieszkania zbiorowego, osiedli jednorodzinnych jak również otwarć widokowych, przestrzeni pieszych i odległości od granicy działki, chodników oraz możliwości wizualnych, odległości widza od obiektu. Odległość ta może w znacznym stopniu ukazać budynek w dwóch różnych perspektywach jak opisuje to Jan Gehl, „Otwarcie dla dwustronnej wymiany doświadczeń nie jest jedynie kwestią szkła i okien, lecz także kwestią odległości. Wąskie parametry ludzkich doświadczeń zmysłowych odgrywają rolę w determinowaniu tego, czy wydarzenie jest otwarte, czy zamknięte. Biblioteka z dużymi oknami, cofnięta o 10 do 15 metrów od ulicy i biblioteka z oknami bezpośrednio wychodzącymi na ulicę stanowią ilustrację tych dwóch sytuacji. W jednym przypadku zobaczyć można budynek z oknami, w drugim - użytkowaną bibliotekę."13.

Specyfika obiektów szkolnych odnosi się w znacznym stopniu do możliwości wykorzystania budynku zarówno w czasie lekcyjnym jak i poza nim. W polskim systemie szkolnictwa uczeń w wieku 7 lat zaczyna swoją edukację i przez kolejne 12 lat, 10 miesięcy w roku będzie uczęszczał na zajęcia lekcyjne. Okres ten jest kluczowym ze względu na rozwój osobowościowy, edukacyjny oraz twórczy. Szkoła poprzez jej architekturę, sposób kształtowania przestrzeni i jej jakość może umożliwić uczniom korzystanie z niej w sposób swobodny, nie narzucając konkretnego sposobu wykorzystania a jedynie tworząc do tego pretekst.

W obiektach takich jak szkoła w Zurichu autorstwa Christiana Kereza, przestrzeń szkoły precyzuje jej przeznaczenie w minimalnym stopniu. Rzuty kondygnacji zostały opracowane w taki sposób aby zarówno przestrzenie korytarzy jak i sali lekcyjnych, komunikacji oraz przestrzeni do spędzania wolnego czasu bądź dodatkowej pracy z nauczycielami były ze sobą jak najbardziej połączone - granice pomiędzy przestrzeniami o konkretnym przeznaczeniu zacierają się co umożliwia twórcze jej wykorzystywanie. W celu uzyskania przestronności wnętrz, wielkość sali lekcyjnych została ograniczona do wymaganego minimum. Sale lekcyjne „zawieszono” w trójpoziomowej, stalowej konstrukcji kratownicowej umożliwiającej swobodne aranżowanie przestrzeni w jej wnętrzu. W budynku przewidziano dodatkowe funkcje publiczne jak audytorium oraz biblioteka. Dostęp do tych funkcji zapewnia droga usytuowana na zewnątrz budynku po jego obwodzie. Jest to ciąg komunikacyjny niezależny od wewnętrznej komunikacji przeznaczonej głównie dla uczniów. Na poziomie parteru utworzono szerokie na ponad dziesięć metrów nadwieszenie ograniczone szklanymi taflami, które np. może być wykorzystane jako bezpieczny, zadaszony plac zabaw. Jednym z najważniejszych, 
niekonwencjonalnych zabiegów projektowych było umiejscowienie sali gimnastycznej na najwyższym poziomie, tworząc tym samym odizolowaną przestrzeń sportową, odizolowaną od miejsc pracy oraz nauki. W projekcie Christian'a Kereza zastosowano nowe tendencje projektowe ściśle związane z ewolucją systemów nauczania, sposobów w jakich może być ono realizowane oraz mentalności społeczeństwa zarówno przełamującej bierny system nauczania jak i akcentującej czynne uczestniczenie z zajęciach szkolnych, twórcze wykorzystywanie przestrzeni nie precyzującej formy spędzania w niej czasu i stwarzającej niemal nieograniczone możliwości jej wykorzystania.

Kolejnym przykładem szkoły umożliwiającej wykorzystanie jej atrium w dowolny sposób jest Orestad College w Kopenhadze. Bryła budynku o powściągliwej formie z zewnątrz, zbliżonej do sześcianu ze szklanymi żyletkami na elewacji oferuje kilkukondygnacyjne atrium, w którym miejsca pracy, biblioteka, sale oraz przestrzenie wypoczynkowe zostały rozlokowane jako bryły o różnej geometrii w taki sposób, że stały się jedynie elementami w jednej wspólnej przestrzeni. We wnętrzu obiektu uczniowie mogą odnaleźć wiele miejsc nie poddanych konkretnym funkcjom a umożliwiające twórcze ich wykorzystanie.

Zarówno szkoła w Zurichu jak i w Kopenhadze są przykładami obiektów manifestujących całkowicie odmienne podejście do wczesnej edukacji oraz współczesnych możliwości dostępu do materiałów naukowych bądź informacji. Dynamicznie rozwijająca się informatyzacja społeczeństwa umożliwia kilkunastoletnim uczniom znaleźć się $\mathrm{w}$ dowolnym miejscu na ziemi w kilka sekund, spacerować ulicami Paryża będąc w Lublinie, oglądać największe aglomeracje miejskie Stanów Zjednoczonych z lotu ptaka nie wychodząc z domu. Postęp cyfrowy sprawia również możliwość kontaktu z drugą osobą, niezależnie od jej odległości, poprzez wiadomości tekstowe, e-mail, skype itp. oraz jej całodobową dostępność komunikacyjną. Te rozwiązania oraz dostęp do informacji wpływ na system edukacji co skutkuje na rozwiązania projektowe odpowiadające na współczesne im wymogi oraz tendencje społeczne.

Jakość przestrzeni, kolor, ilość światła oraz inne czynniki nieustannie odbierane są przez nasze zmysły, kształtują samopoczucie oraz tworzą tło do warunków pracy, nauki bądź wypoczynku. Człowiek tworząc architekture wpływa na siebie samego. Skala pomieszczeń, wielkość budynku, kształt przestrzeni wywołuja emocje i wpływaja na samopoczucie użytkowników. Nasze zmysty reaguja na wszystkie bodźce odbierane od otoczenia stworzonego przez architekta ${ }^{14}$.

Wpływem bodźców zewnętrznych środowiska oddziałujących nieustannie na człowieka zajmuje się psychologia architektury interpretująca zmiany zachodzące w człowieku pod wpływem różnych czynników tj pobudzenie bądź blokowanie ludzkiej aktywności, pomoc bądź utrudnienie realizacji wybranych celów a także wpływ na samopoczucie i zachowanie człowieka. Wszystkie powyższe reakcje oraz stany emocjonalne człowieka są ściśle związane z otoczeniem w jakim w danej chwili przebywa. Anna Bać w swojej pracy doktorskiej opisuje wyniki badań niemieckiego profesora Christiana Rittelmeyera, które udowadniają powiązanie pomiędzy rozwiązaniami architektonicznymi a reakcją uczniów. Badania polegały na zamknięciu uczniów w wąskim i ciasnym pomieszczeniu oraz poddaniu analizie ich samopoczucia. Reakcje badanych uczniów były skrajnie różne. Pierwsza grupa odczuwała niekorzystne samopoczucie objawiające się napięciem mięśni, zaburzeniami rytmu oddechu oraz chęci jak najszybszego wydostania się z przestrzeni, w której zostali zamknięci. Druga grupa badanych odczuwała korzystne samopoczucie powiązane ze znalezieniem się w przestrzeni bezpiecznej, przytulnej. Wyniki tych badań jednoznacznie potwierdzają, że fizyczna przestrzeń, w której znajduje się człowiek może wywierać ogromny wpływ na jego stan emocjonalny, "istotny jest zatem dobór rozwiązań architektonicznych zgodnych z omówionymi „prawidłowościami i sensem działania zmystów"15.

14 Pabich 2013

15 Bać 2003 


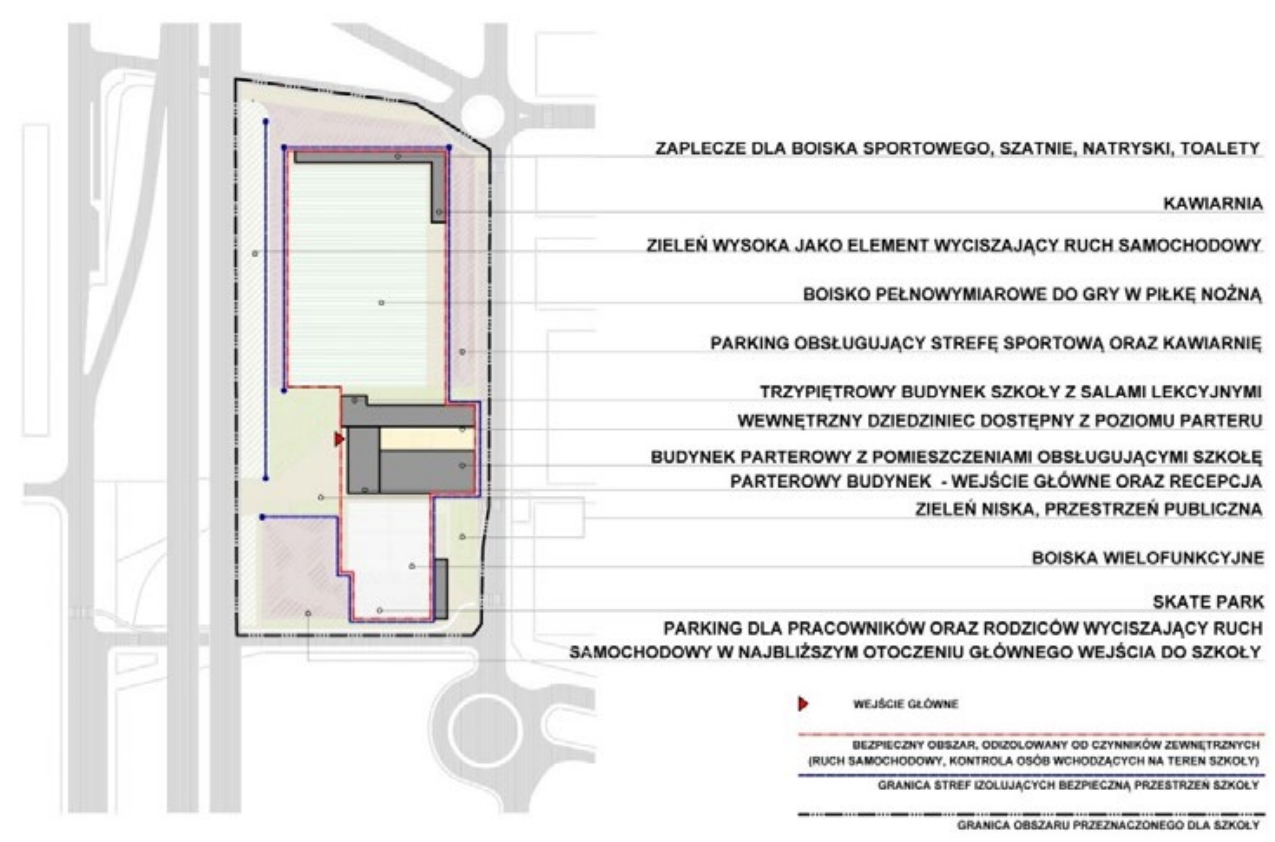

Ryc. 1 Schemat analityczny zagospodarowania terenu szkoły podstawowej w Cornelia de Llobregat w Barcelonie, Hiszpania, (opr. Wojciech Kocki)

Fig. 1 Analytic Diagram of site plan of elementary school in Cornelia de Llobregat in Barcelona, Spain, (aut. Wojciech Kocki)

Przykładowym, współczesnym obiektem szkoły, który posiada wiele rozwiązań projektowych wpływających na bezpieczeństwo uczniów jak i stwarzający możliwości ich rozwoju w czasie pozalekcyjnym jest szkoła podstawowa w Barcelonie, w dzielnicy Alameda.

Układ funkcjonalny zagospodarowania niewielkiej działki (standardowej wielkości dla tego typu stref miejskich) dla szkoły w Cornelia de Llobregat jest zwartym oraz czytelnym rozplanowaniem zarówno niezbędnych jak i dodatkowych funkcji towarzyszących budynkowi.

Obiekt zaprojektowano w formie dwóch brył różniących się pod względem funkcjonalnym, połączonych za pomocą wewnętrznego dziedzińca. Budynek został otoczony różnego rodzaju funkcjami: od strony północnej trawiastym boiskiem do gry w piłkę nożną wraz zapleczem sanitarnym, zespołem szatni, trybunami oraz kawiarnią, od strony wschodniej ciągiem zieleni wysokiej na poziomie boiska, przestrzenią publiczną $\mathrm{w}$ formie niewielkiego skweru będącego przedpolem dla głównego wejścia do szkoły, od strony południowej usytuowano dwa, mniejsze, dodatkowe boiska oraz skate park, parking dla rodziców przywożących dzieci do szkoły oraz pas zieleni niskiej zamykającej przestrzeń parkingu, od strony wschodniej znajduje się chodnik oraz droga rowerowa wraz z parkingiem na poziomie boiska.

Istotnym zagadnieniem w sposobie zagospodarowania działki było potraktowanie głównego wejścia jako bezpiecznej przestrzeni, odizolowanej w jak największym stopniu od ruchu samochodowego oraz płynących z tego względu niebezpieczeństw dla uczniów. Wszystkie niezbędne elementy towarzyszące infrastrukturze szkoły tworzą jednocześnie bezpieczną barierę da budynku jak i swobodny dostęp do wszystkich elementów z poziomu parteru. Od strony wschodniej znajduje się sześciopasmowa droga ekspresowa dla której barierą akustyczną jest pas zieleni wysokiej. Wejście główne do budynku nie jest powiązane bezpośrednio z ruchem samochodowym, jedynie z parkingiem. Wszystkie wspólne pomieszczenia szkolne jak stołówka, kuchnia, sala sportowa, szatnie, pokój nauczycielski, pomieszczenia techniczne oraz 
wejście główne znajdują się w parterowej części wraz z placem zabaw. Wszystkie sale lekcyjne znajdują się w trzykondygnacyjnym budynku połączonym z częścią parterową otwartą klatką schodową. Ze względu na warunki geograficzne oraz duże nasłonecznienie, doświetlenie sali zapewniono od strony północnej. Niewielki łącznik pomiędzy dwoma budynkami jest wejściem głównym mieszczącym recepcję oraz wejście do biblioteki umożliwiające bezpośredni do niej dostęp. Elewację południową trzykondygnacyjnej części tworzy rustykalna ściana zaprojektowana z ceramicznych prefabrykowanych elementów $(300 \times 200 / 300 \times 22 \mathrm{~mm})$ ustawionych względem siebie pod zmiennym kątem co umożliwia w znacznym stopniu ograniczenie promieni słonecznych. Wszystkie elementy ceramiczne posiadają przeszklone, kolorowe otwory. Kolorystyka elewacji jest odmienna w zależności od kierunku obserwacji widza, od strony zachodniej przybiera kolorystykę barw chłodnych (zielonego, niebieskiego) a od strony wschodniej barw ciepłych (żółci, pomarańczy, brązów). Ten zabieg ukazuje uzyskanie dwóch rodzajów elewacji poprzez zastosowanie koloru. Elewacja wschodnia została pozbawiony otworów okiennych oraz drzwiowych zapewniając maksymalną izolację od ruchu ulicznego.

Sposób w jaki zaprojektowano budynek szkoły oraz usytuowanie względem niego wszystkich elementów zagospodarowania terenu umożliwia stworzenie bezpiecznego miejsca w którym odizolowano przestrzeń dla uczniów od ruchu samochodowego, hałasu a także poprzez wejście główne i recepcję, kontrolę osób wchodzących na teren obiektu. Przykład szkoły podstawowej autorstwa biura projektowego Mestura Arquitectos tworzy miejsce będące przykładem bezpiecznej przestrzeni dla nauki oraz spędzania czasu wykorzystując kawiarnię, biblioteką, boiska czy skate park.

Podsumowując, kreowanie fizycznej przestrzeni szkolnej jako obiektu architektonicznego zależy od wielu czynników związanych z samopoczuciem człowieka, bodźców jakie odbiera poprzez zmysły i jego interakcji z otoczeniem. Psychologiczny aspekt środowiska w jakim przebywają dzieci staje się niezwykle istotnym elementem, który jak udowodniono ${ }^{16}$ ma znaczny wpływ na efektywność pracy i nauki, zwiększenia jej o nawet $25 \%$. Powiązanie różnych dziedzin naukowych, czasami pozornie bardzo odmiennych, w procesie projektowym może przyczynić się do powstania nowej jakości architektury w oparciu o min. nowe technologie, świadomość czynników wpływających na samopoczucie człowieka, dynamicznie zmieniającego się sposobu wymiany informacji oraz jej dostępu a także możliwość komunikacji międzyludzkiej. W dobie dynamicznych zmian ekonomicznych i różnic w sposobie życia ludzi, ich mentalności, tradycji i historii, architektura poprzez formę staje się odpowiedzią uwzględniającą niemal wszystkie te aspekty. 


\title{
PIŚMIENNICTWO
}

Bać A., 2003. Wybrane zagadnienia projektowania szkót na przykładzie realizacji Wiedeńskich lat 90 XX wieku.

Bańka A., 2002. Społeczna psychologia środowiskowa. Warszawa, Wyd. Nauk. „Scholar”, str. 19.

Barrett P., Zhang Y., 2009. Optimal learning spaces, design implications for primary schools, SCRI Research Report.

Barrett P., Zhang Y., Moffat J., Kobbacy K., 2012. A holistic, multi - level analysis identyfying the impact of classroom design on pupils' learning, University of Salford.

Borowik J., 2010. COLLOQUIUM Wydziału Nauk Humanistycznych i Społecznych AMW. Nr 2, ss. 85-94.

Cichy D., Strumińska-Doktór A., 2010. Poradnik do oceny procesu nauczania-uczenia się w szkole podstawowej. Warszawa, Państwowa Inspekcja Sanitarna, str. 6.

Gehl J., 2013. Życie między budynkami, Użytkowanie przestrzeni publicznych, RAM, str. 121.

Gifford, R., 2007. Environmental Psychology: Principles and Practice. Colville, Optimal Books.

Izdebska J., 1978. Czas wolny dzieci i młodzieży. [w:] Przecławski K. (Red.): Czas wolny dzieci i młodzieży w Polsce. Warszawa, WSiP, s.23.

Matyjas B., 2003. Czas wolny [w:] Różycka E. (Red.): Encyklopedia pedagogiczna XXI wieku. T. 1, A-F. Warszawa, Wydawnictwo Akademickie „Żak”, ss. 561-562.

Nair P., Fielding R., 2005. The language of school design, National Clearinghouse for Educational Facilities and The Knowledge Works Foundation.

Nalaskowski A., 2013. Szkolne gry przestrzenne. Meritum, Nr 1 (28), ss. 5-11.

OECD, 2006. 21st Century Learning Environment. Wyd. OECD.

Okoń W., 1984. Słownik Pedagogiczny, Warszawa, PWN, s. 295.

Pabich M., 2013. Mario Botta. Nikt nie rodzi się architektem, Wyd. Politechniki Łodzkiej.

Skorodzień A., 2013. Małe dziecko w przestrzeni szkolnej. Meritum, Nr 1 (28), ss. 3435.

Toffler A., 2000. Szok przyszłości. Poznań, Wyd. Zysk i S-ka, s. 402-403.

\section{PHYSICAL SPACE OF SCHOOL - CONTEMPORARY DESIGN INDEAS}

\begin{abstract}
Contemporary design ideas of school buildings have dramatically changed since eighties. Including a function and searching for added value which is not strictly related with function of school but being an excuse for staying in the space of building and using it individually according to needs. Great value for design process have an environmental psychology which search for way of developing a space and its interaction with people.
\end{abstract}

Key words: school, design, environmental psychology, physical space 